\title{
BRACHIAL PLEXUS INJURIES - REVIEW OF THE ANATOMY AND THE TREATMENT OPTIONS
}

\author{
Sofija Pejkova $^{1}$, Venko Filipce ${ }^{2}$, Igor Peev ${ }^{1}$, Bisera Nikolovska ${ }^{1}$, \\ Tomislav Jovanoski ${ }^{1}$, Gordana Georgieva ${ }^{1}$, Blagoja Srbov ${ }^{1}$ \\ ${ }^{1}$ University Clinic for Plastic and Reconstructive Surgery, Skopje, RN Macedonia \\ ${ }^{2}$ University Clinic for Neurosurgery, Skopje, RN Macedonia
}

Corresponding author: Sofija Pejkova, University Clinic for Plastic and Reconstructive Surgery, Skopje, North Macedonia, Email: pejkova@gmail.com

\begin{abstract}
Brachial plexus injuries are still challenging for every surgeon taking part in treating patients with BPI. Injuries of the brachial plexus can be divided into injuries of the upper trunk, extended upper trunk, injuries of the lower trunk and swinging hand where all of the roots are involved in this type of the injury. Brachial plexus can be divided in five anatomical sections from its roots to its terminal branches: roots, trunks, division, cords and terminal branches. Brachial plexus ends up as five terminal branches, responsible for upper limb innervation, musculocutaneous, median nerve, axillary nerve, radial and ulnar nerve. According to the findings from the preoperative investigation combined with clinically found functional deficit, the type of BPI will be confirmed and that is going to determine which surgical procedure, from variety of them (neurolysis, nerve graft, neurotization, arthrodesis, tendon transfer, free muscle transfer, bionic reconstruction) is appropriate for treating the patient.
\end{abstract}

Keywords: BPI; brachial plexus injuries; anatomy of brachial plexus, treatment options for brachial plexus injuries, bionic reconstruction

\section{INTRODUCTION}

Brachial plexus injuries are still challenging for every surgeon taking part in treating the patient with BPI, needing to know the complex anatomy providing function of the upper limb and possible treatment options that will do the best in restoring the function of the upper limb. It can be seen as a complex network of nerve fibers, arising from anterior branches of the lower four cervical spinal nerves $(\mathrm{C} 5-\mathrm{C} 8)$ and the first thoracic spinal nerve (T1) $[1,2]$. The upper limb, part of the upper thoracic wall and part of the cervical structures are innervated by the bra- chial plexus. The anatomical position makes it vulnerable during trauma, and also very often during childbirth $[3,4]$. Using motorcycles as a transport more often in the last years have been the reason for increasing the number of brachial plexus injuries $[5,6]$. BPI can be divided into injuries of the upper trunk (Erb-Duchene C5/C6), extended upper trunk (Erb-Duchene C5, C6, C7), injuries of the lower trunk (Dejerine-Klumpke C8/T1) and swinging hand where all of the roots are involved in this type of the injury. If the upper trunk is injured only, the prognosis is better 
compared to the isolated trauma of the divisions, upper roots or the lower trunk [7]. Starting from the 1940s and 1950s with more serious approach to the treatment of this kind of injuries, from Seddon [8] and Bateman [9], different type of operative procedures were involved in the treatment, including amputation or arthrodesis of the shoulder, elbow or the wrist, depending from the level of injury. In the 1963 again Seddon [10] proposed nerve graft as a surgical option when there is a loss of the nerve segment, instead of the drawing together upper and lower part of the nerve, and keeping the patient in unnatural position or even shortening the collar bone. Five or six months after the injury it was considered to wait before indicating the injury, in the 1990s, but the development of more precise imaging diagnostic methods and electrical studies indicate surgery to be done earlier that more of three months, because of the better prognosis of the nerve regeneration [11]. Suturing intact nerve to the injured one, known as a technique of neurotization, have boost the results after brachial plexus surgery.

\section{ANATOMY OF THE BRACHIAL PLEXUS}

Brachial plexus can be divided in five anatomical section from its roots to its terminal branches. All of the spinal nerves have anterior root (radix ventralis) that provide motor nerve fibers and posterior root (radix dorsalis) that provide sensitive nerve fibers. When this two roots merge, the spinal nerve is formed but shortly after, in the intervertebral aperture it gives 4 branches, from which anterior is the thicker one that take roll in forming of the brachial plexus. Roots of the brachial plexus are the anterior branches of the lower four cervical spinal nerves (C5-C8) and first thoracic spinal nerve (T1) in most of the cases [12, 13], but there are also some anatomical variation that include anterior branches from C4 to C5 (that is known as a prefixed plexus brachialis) and anterior branches from T2 to T1 (also known as post fixed brachial plexus). The first three roots arise above the vertebral body while the last two exits below their numbered vertebral body. The roots give same segmental supply to the prevertebral and scalene muscles just before they form trunks, placed between the middle and anterior scalene muscles [1, 12, 13]. Going from the upper part distally, three branches divide directly from the roots: the dorsal scapular nerve (have origin from $\mathrm{C} 5$ ), the long thoracic nerve (have contribution from $\mathrm{C} 5, \mathrm{C} 6$ and $\mathrm{C} 7$ ) and the first intercostal nerve that partially arise from $\mathrm{T} 1$ root. We need to know that in this level, the phrenic nerve receives some nerve fibers from the brachial plexus, but also gives contribution to it, that can be noticed from changing the thickness of the nerve when it passes C5 root. Brachial plexus trunks are located in the neck region, in the triangle know as the posterior cervical triangle. There are three trunks, upper, middle and lower trunk. The upper trunk is formed by merging the $\mathrm{C} 5$ and $\mathrm{C} 6$ nerve roots, the middle trunk is an extension of the $\mathrm{C} 7$ nerve root and the lower trunk is made from the $\mathrm{C} 8$ and $\mathrm{T} 1$ nerve roots. At this anatomical section only the upper trunk has lateral branches, subclavian nerve, like anterior branch from upper trunk, and suprascapular nerve that is posterior branch of the same trunk [13], that will be discussed later in out paper with all of the lateral and terminal branches. Roots and trunks according to its anatomical correlation with collar bone are located above its level or in the space know as a supraclavicular space. Posterior to the collar bone each of these three roots divide into two divisions, anterior and posterior with no lateral branches given. Going at the level below the collar bone, beneath pectoralis minor muscle, the division starts to form the posterior, lateral and medial cords. The names of the cords are given according to their position to the axillary artery in its middle portion. The lateral cord lies lateral from it, the posterior is behind this portion, and the medial cord after crossing the axillary artery lies medial to it $[13,14]$. The anterior divisions of the upper and middle trunk form the lateral cord, the medial cord is a continuation of the anterior division of the lower trunk and the posterior divisions of all three trunks form posterior cord. Because of this complex network with merging and dividing of the nerve fibers starting from the roots, the three cords have inputs from different levels, and only the posterior cord receives input from all the roots from C5 to T1. The upper subscapular, long thoracic nerve and the lower subscapular nerve are lateral branches from the posterior cord that end up with two terminal branches, radial and axillary nerve. C5, C6 and C7 trough upper and middle trunk anterior divisions, give input to the 
lateral cord. From the lateral cord there is only one lateral branch, lateral pectoral nerve, and then it ends up or terminates giving up lateral root for median nerve and one of the terminal branch, musculocutaneous nerve. The anterior division of the lower trunk that is formed by $\mathrm{C} 8$ and $\mathrm{T} 1$ nerve roots, continues in the medial cord, so the lateral and terminal branches from this cord have input from $\mathrm{C} 8$ and $\mathrm{T} 1$ respectively. Arising from this medial cord we have three lateral branches, medial pectoral nerve, medial cutaneous nerve of the arm and medial cutaneous nerve of the forearm. The medial cord terminates in the ulnar nerve and the medial root of the median nerve that unites with its lateral $\operatorname{root}[12,13,14]$.

\subsection{Nerves arising from brachial plexus}

\subsubsection{Lateral branches}

Dorsal scapular nerve, long thoracic nerve and the first intercostal nerve are the three branches that arise directly from the nerve roots. We have mention that $\mathrm{C} 5$ nerve root gives nerve fibers that merge with the one from the $\mathrm{C} 3$ and $\mathrm{C} 4$ nerve root, forming phrenic nerve. Subclavian nerve and suprascapular nerve are lateral branches that give rise from the superior trunk. The lateral pectoral nerve is a branch of the lateral cord, upper subscapular, thoracodorsal and lower subscapular nerve are branches that come from posterior cord, while the medial pectoral nerve, medial cutaneous nerve of the arm and medial cutaneous nerve of the forearm derive from medial cord.

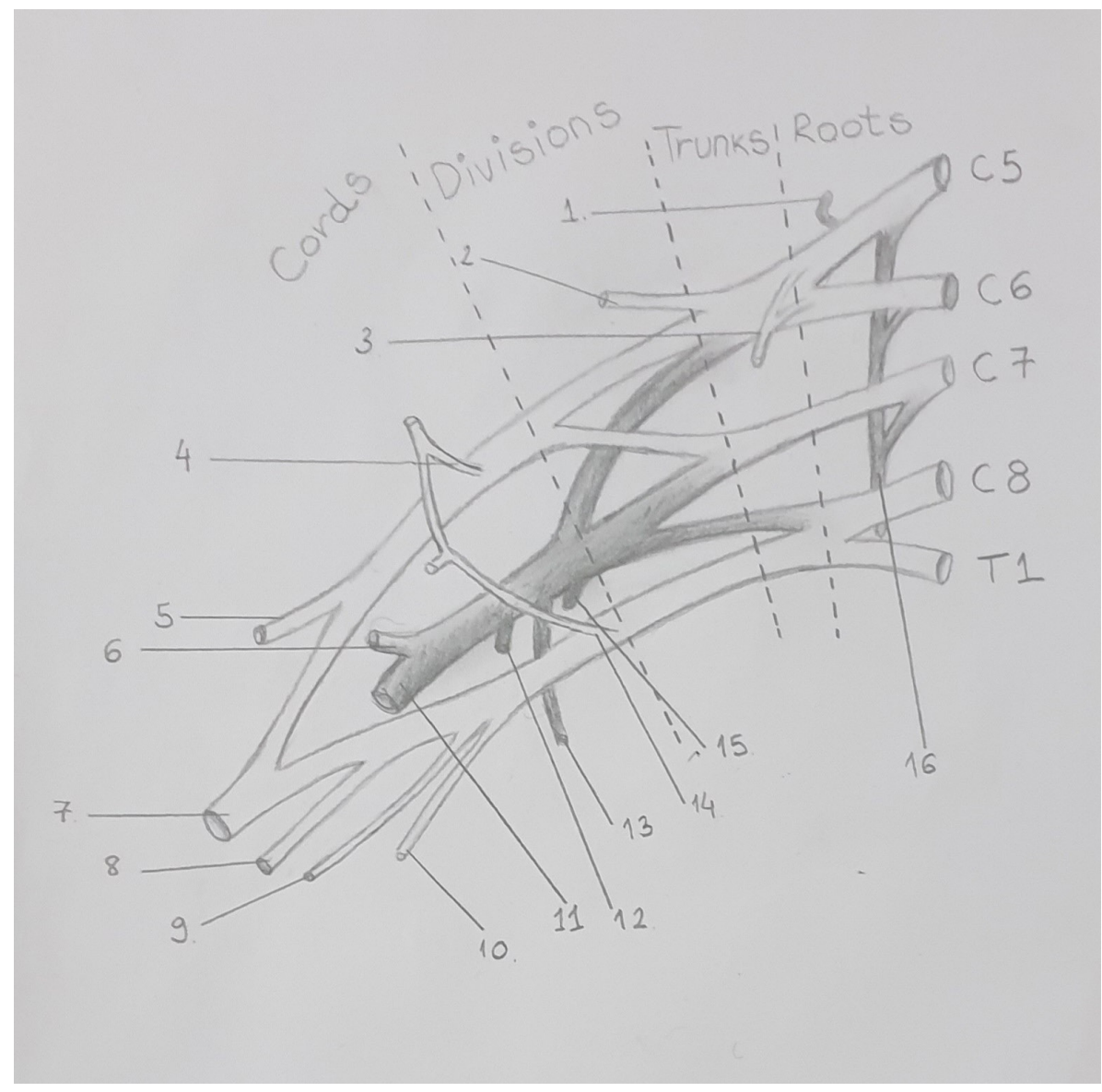

1. Dorsal scapular nerve; 2. Suprascapular nerve; 3.Nerve to subclavius; 4. Lateral pectoral nerve; 5. Musculucutaneous nerve; 6. Axillary nerve; 7.Median nerve; 8. Ulnar nerve; 9. Medial cutaneous nerve of the forearm; 10. Medial cutaneous nerve of the arm; 11. Radial nerve; 12. Lower subscapular nerve; 13. Thoracodorsal nerve; 14. Medial pectoral nerve; 15. Upper subscapular nerve; 16 . Long thoracic nerve

Fig. 1. Brachial plexus 
Table 1. Lateral branches of the brachial plexus

\begin{tabular}{|c|c|c|c|c|}
\hline Lateral branches & Roots & Innervation & Function & Clinical deficits \\
\hline $\begin{array}{l}\text { Dorsal scapular nerve } \\
\text { (Nervus dorsalis } \\
\text { scapulae) }\end{array}$ & $\mathrm{C} 5$ & 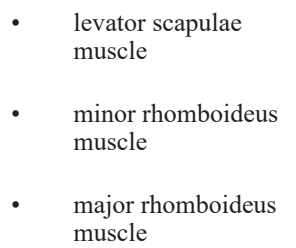 & $\begin{array}{l}\text { - Elevate scapula } \\
\text { - } \quad \text { Pulls the scapula to the midline }\end{array}$ & $\begin{array}{l}\text { Unable to pulls the } \\
\text { shoulder back and } \\
\text { scapula is farther } \\
\text { from the midline } \\
\text { compared to the } \\
\text { uninjured side }\end{array}$ \\
\hline $\begin{array}{l}\text { Long thoracic nerve } \\
\text { (Nervus thoracicus } \\
\text { longus) }\end{array}$ & $\begin{array}{l}\mathrm{C} 5, \mathrm{C} 6 \\
\text { and } \mathrm{C} 7\end{array}$ & $\begin{array}{l}\text { - serratus anterior } \\
\text { muscle }\end{array}$ & $\begin{array}{l}\text { - Keep the scapula close to the } \\
\text { posterior wall chest } \\
\text { Helps elevation of the arm and } \\
\text { lifting weight overhead and also } \\
\text { assist in respiration }\end{array}$ & $\begin{array}{l}\text { Winging of the } \\
\text { scapula on the } \\
\text { injured side }\end{array}$ \\
\hline $\begin{array}{l}\text { First intercostal nerve } \\
\text { (Nervus intercostalis) }\end{array}$ & $\mathrm{T} 1$ & $\begin{array}{l}\text { - } \\
\text { a sensory supply to } \\
\text { of skin in the first } \\
\text { intercostal space } \\
\text { motor supply to } \\
\text { the first intercostal } \\
\text { muscle }\end{array}$ & $\begin{array}{l}\text { Elevating and depressing the } \\
\text { rib cage during the process of } \\
\text { breathing }\end{array}$ & \\
\hline $\begin{array}{l}\text { Subclavian nerve } \\
\text { (Nervus subclavius) }\end{array}$ & $\begin{array}{l}\text { C5 and } \\
\text { C6 }\end{array}$ & - $\quad$ subclavian muscle & $\begin{array}{l}\text { Take part in elevation of the first } \\
\text { rib and depression of the collar } \\
\text { bone }\end{array}$ & \\
\hline $\begin{array}{l}\text { Suprascapular } \\
\text { nerve (Nervus } \\
\text { suprascapularis) }\end{array}$ & $\begin{array}{l}\text { C5 and } \\
\text { C6 }\end{array}$ & $\begin{array}{ll}\text { - } & \text { supraspinatus } \\
\text { muscle } \\
\text { - } \quad \text { infraspinatus muscle }\end{array}$ & $\begin{array}{l}\text { Abduction of the arm, pulls the } \\
\text { head of the humerus medial } \\
\text { External rotator of the shoulder }\end{array}$ & $\begin{array}{l}\text { Back pain and } \\
\text { problems with } \\
\text { abduction and } \\
\text { external rotation of } \\
\text { the arm }\end{array}$ \\
\hline $\begin{array}{l}\text { Lateral pectoral nerve } \\
\text { (Nervus pectoralis } \\
\text { lateralis) }\end{array}$ & $\begin{array}{l}\mathrm{C} 5, \mathrm{C} 6 \\
\text { and } \mathrm{C} 7\end{array}$ & $\begin{array}{l}\text { - major pectoral } \\
\text { muscle }\end{array}$ & $\begin{array}{l}\text { Flexion of the humerus, adduct } \\
\text { the humerus, medial rotation of } \\
\text { the humerus and keeping the arm } \\
\text { attached to the trunk of the body }\end{array}$ & $\begin{array}{l}\text { Atrophy of the } \\
\text { sternal part } \\
\text { of pectoral } \\
\text { major muscle } \\
\text { and limitation } \\
\text { of shoulder } \\
\text { movement }\end{array}$ \\
\hline $\begin{array}{l}\text { Upper subscapular } \\
\text { nerve (Nervus } \\
\text { subscapularis } \\
\text { proximalis) }\end{array}$ & $\begin{array}{l}\text { C5 and } \\
\text { C6 }\end{array}$ & - $\quad$ subscapular muscle & $\begin{array}{l}\text { Preventing displacement of } \\
\text { the head of the humerus and } \\
\text { internally rotates the humerus }\end{array}$ & $\begin{array}{l}\text { Difficulty during } \\
\text { internal rotation } \\
\text { of the shoulder } \\
\text { and stability of the } \\
\text { joint }\end{array}$ \\
\hline $\begin{array}{l}\text { Lower subscapular } \\
\text { nerve (Nervus } \\
\text { subscapularis distalis) }\end{array}$ & $\begin{array}{l}\text { C5 and } \\
\text { C6 }\end{array}$ & $\begin{array}{l}\text { subscapular muscle } \\
\text { - lower part } \\
\text { also give motor } \\
\text { branches to teres } \\
\text { major muscle }\end{array}$ & $\begin{array}{l}\text { adducts, internal rotate shoulder, } \\
\text { depresses and abducts scapula. }\end{array}$ & $\begin{array}{l}\text { Difficulty during } \\
\text { internal rotation of } \\
\text { the shoulder and } \\
\text { adduction }\end{array}$ \\
\hline $\begin{array}{l}\text { Thoracodorsal } \\
\text { nerve (Nervus } \\
\text { thoracodorsalis) }\end{array}$ & $\begin{array}{l}\mathrm{C} 6, \mathrm{C} 7 \\
\text { and } \mathrm{C} 8\end{array}$ & $\begin{array}{l}\text { latissimus dorsi } \\
\text { muscle }\end{array}$ & $\begin{array}{l}\text { external rotation of the trunk but } \\
\text { also is responsible for adduction, } \\
\text { internal rotation and extension on } \\
\text { the shoulder }\end{array}$ & $\begin{array}{l}\text { weakness } \\
\text { in shoulder } \\
\text { movement }\end{array}$ \\
\hline $\begin{array}{l}\text { Medial pectoral nerve } \\
\text { (Nervus pectoralis } \\
\text { medialis) }\end{array}$ & $\begin{array}{l}\mathrm{C} 8 \text { and } \\
\mathrm{T} 1\end{array}$ & - $\quad$ pectoral muscles & & \\
\hline $\begin{array}{l}\text { Medial cutaneous nerve } \\
\text { of the arm (Nervus } \\
\text { cutaneous brachii } \\
\text { medialis) }\end{array}$ & $\begin{array}{l}\mathrm{C} 8 \text { and } \\
\mathrm{T} 1\end{array}$ & $\begin{array}{l}\text { sensory supply } \\
\text { skin over the lower } \\
\text { medial and posterior } \\
\text { part of the arm }\end{array}$ & & \\
\hline $\begin{array}{l}\text { Medial cutaneous nerve } \\
\text { of the forearm (Nervus } \\
\text { cutaneous antebrachii } \\
\text { medialis) }\end{array}$ & $\begin{array}{l}\mathrm{C} 8 \text { and } \\
\mathrm{T} 1\end{array}$ & $\begin{array}{l}\text { sensory innervation } \\
\text { of the skin over the } \\
\text { biceps muscle, on } \\
\text { on the ulnar side of } \\
\text { the forearm from } \\
\text { elbow to the wrist }\end{array}$ & & \\
\hline
\end{tabular}




\subsubsection{Terminal branches}

Brachial plexus ends up as five terminal branches, responsible for the upper limb inner- vation, musculocutaneous, median nerve, axillary nerve, radial and ulnar nerve.

Table 2. Terminal branches of the brachial plexus

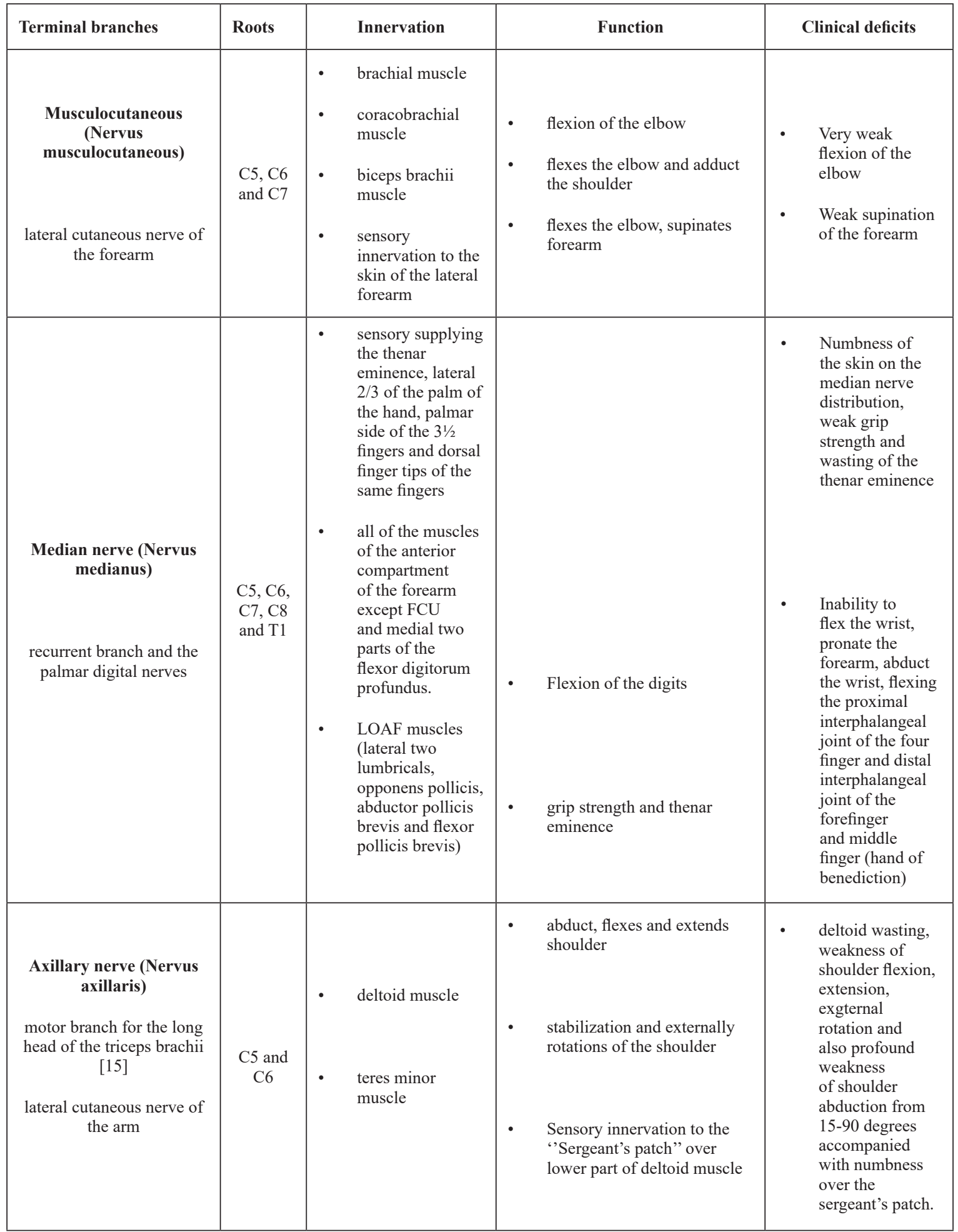




\begin{tabular}{|c|c|c|c|c|}
\hline $\begin{array}{l}\text { Radial nerve (Nervus } \\
\text { radialis) }\end{array}$ & $\begin{array}{l}\mathrm{C} 5, \mathrm{C} 6 \text {, } \\
\mathrm{C} 7, \mathrm{C} 8 \\
\text { and } 11\end{array}$ & $\begin{array}{l}\text { triceps brachii, } \\
\text { brachialis, } \\
\text { brachioradialis, } \\
\text { anconeus and } \\
\text { extensor carpi } \\
\text { radialis longus } \\
\\
\text { sensory supply to } \\
\text { the dorsum of the } \\
\text { hand, thumb and } \\
\text { three and a half } \\
\text { fingers without } \\
\text { nail beds } \\
\text { extensor carpi } \\
\text { radialis brevis and } \\
\text { supinator muscle } \\
\text { extensor } \\
\text { digitorum, } \\
\text { extensor digiti } \\
\text { minimi, extensor } \\
\text { carpi ulnaris, } \\
\text { abductor pollicis } \\
\text { longus, extensor } \\
\text { pollicis brevis, } \\
\text { extensor pollicis } \\
\text { longus and } \\
\text { extensor indicis }\end{array}$ & $\begin{array}{l}\text { extension of the forearm and } \\
\text { hand } \\
\text { - sensation of the skin in the } \\
\text { lateral arm, back side of the } \\
\text { forearm, half of the dorsum } \\
\text { of the hand (radial) and the } \\
\text { dorsal skin covering the three } \\
\text { and a half fingers without } \\
\text { their nail beds } \\
\text { extension of the fingers }\end{array}$ & $\begin{array}{l}\text { - } \text { wrist drop } \\
\text { supination can be } \\
\text { lost or weak } \\
\\
\text { - loss of sensation } \\
\text { of the skin in } \\
\text { the lateral arm, } \\
\text { back side of the } \\
\text { forearm, half of } \\
\text { the dorsum of } \\
\text { the hand (radial) } \\
\text { and the dorsal } \\
\text { skin covering the } \\
\text { three and a half } \\
\text { fingers without } \\
\text { their nail beds. } \\
\text { - extension of the } \\
\text { fingers will be } \\
\text { lost }\end{array}$ \\
\hline $\begin{array}{l}\text { Ulnar nerve (Nervus } \\
\text { ulnaris) } \\
\text { digital branches }\end{array}$ & $\begin{array}{c}\mathrm{C} 8 \text { and } \\
\mathrm{T} 1\end{array}$ & $\begin{array}{l}\text { - } \begin{array}{l}\text { flexor carpi } \\
\text { ulnaris and } \\
\text { medial half of } \\
\text { deep flexors }\end{array} \\
\text { palmar branch } \\
\text { gives sensor } \\
\text { supply to the } \\
\text { hypothenar } \\
\text { dorsal branches } \\
\text { for sensory } \\
\text { innervation of the } \\
\text { ulnar side of the } \\
\text { hand and upper } \\
\text { part of the one } \\
\text { and a half fingers } \\
\text { motor supply to } \\
\text { the hypothenar } \\
\text { muscles } \\
\text { (opponens digiti } \\
\text { minimi, abductor } \\
\text { digiti minimi } \\
\text { and flexor digiti } \\
\text { minimi brevis) } \\
\text { third and fourth } \\
\text { lumbrical } \\
\text { muscles, dorsal } \\
\text { and palmar } \\
\text { interossei muscle, } \\
\text { adductor pollicis } \\
\text { and the deep head } \\
\text { of flexor pollicis } \\
\text { brevis }\end{array}$ & $\begin{array}{l}\text { Flexion of the wrist } \\
\text { - Sensation over the } \\
\text { hypothenar region } \\
\text { - Sensation over ulnar side of } \\
\text { the hand and upper part of } \\
\text { one and a half finger }\end{array}$ & $\begin{array}{l}\text { At elbow } \\
\text { level - loss of } \\
\text { sensation to the } \\
\text { ulnar side of the } \\
\text { hand and the } \\
\text { one and a half } \\
\text { finger from volar } \\
\text { and dorsal side, } \\
\text { accompanied } \\
\text { with difficulty in } \\
\text { the flexion of the } \\
\text { wrist and 4th and } \\
\text { 5th finger - claw } \\
\text { hand deformity } \\
\text { On the clinical } \\
\text { finding will } \\
\text { be noticed the } \\
\text { weakness of } \\
\text { adduction of the } \\
\text { thumb. } \\
\text { Damaged ulnar } \\
\text { nerve at the } \\
\text { level of the wrist } \\
\text { represent with } \\
\text { loss of sensation } \\
\text { only at the } \\
\text { ulnar side of the } \\
\text { palm and more } \\
\text { deformed claw } \\
\text { hand deformity. } \\
\text { Adduction of the } \\
\text { thumb is also } \\
\text { lost. }\end{array}$ \\
\hline
\end{tabular}




\section{TREATMENT OPTIONS FOR BPI}

Low energy penetrating injuries or high energy injuries that lead to amputation of the upper arm are very uncommon, open wounds BPI, seeking for nerve repair quickly after the time of injury, when general health status of the patient allow us. If it is impossible to do the nerve reparation at that time, pain control, starting the process of rehabilitation and evaluating the injury through electromyography, CT myelography or MRI should be done preoperative giving us needed evidence for the type of the injury. In closed wounds type of brachial plexus injuries, surgical treatment might be planed after 3-6 months if there is no sign of functional recovery, with same preoperative preparation. If all of the preoperative findings suggest of eventual preganglionic lesions, the transfer of the nerve is a choice of operative treatment that need to be done.

\subsection{Non-surgical treatment}

All the patients that do not go under surgical treatment in the moment or early after the trauma, need to start with physical therapy that will strengthen the muscles that are functional and keep range of motion of the upper extremity, otherwise stiffness of the hand is unavoidable. Chronic edema as a result of no movement in the arm muscles and sympathetic denervation led to loss of the vascular tonus, and is decreased by keeping the arm in elastic bandages and raised. Pain, more significant in patient with avulsions of the roots, is managed by using NSAIDs and opioids in the beginning and antiepileptics drugs later, when neuropathic pain occur. If there is no relief of the pain with medications, surgical treatment for destroying the signal transmission should be taken in consideration $[16,17]$

\subsection{Surgical treatment}

According to the findings from the preoperative investigation combined with the clinically found functional deficit, the type of BPI will be confirmed, and that will determine which surgical procedures, from variety of them, is appropriate for treating the patient. The decision for bringing back the stability of the shoulder or flexion of the elbow sometimes have to be made in view of the fact that small amount of nerve units are available.

\subsubsection{Neurolysis}

As one of the early stages of nerve reconstruction in BPI, neurolysis or releasing the nerve from fibrous tissue, may help in cases with neuroma in continuity if there are enough viable fibers. Nowadays it is possible during surgery, with electrical studies, nerve action potential (NAP), to determine the viable nerve fibers, and to decide whether to do resection of that part of the nerve and then nerve transfer or neurolysis will have satisfactory outcome. But, the clinical outcome of just neurolysis is hard to recognize, because improvement may be result of many other factors.

\subsubsection{Nerve graft}

Introduced by Seddon, in 1963 [10], the nerve graft technique has been used by many others surgeons, confirming good outcome results in selected BPI $[18,19]$. Healthy upper end of the nerve, without axial damage is one of the condition for good outcome, depending also on the length and number of used nerve grafts, and the scar found at the place that can lead to bigger gap between the ends. When there are more nerves injured, prioritization which nerve to be repaired with nerve graft needs to be done, giving the priority on the flexion in the elbow joint, abduction the shoulder and giving sensation of the forearm. Medial cutaneous nerve of the forearm or sensory branch of the ulnar nerve are the usual donor nerves from the arm, but mostly the sural nerve has been used as a nerve donor in addition of the length that can be provided (up to $40 \mathrm{~cm}$ ). Nerve grafts that are less than $10 \mathrm{~cm}$ [18] give better functional results, when they are grafted and in the same time inverted, which will minimize the chance of losing some axial branches. Using the fibrin glue, recently, reduced the need of stitches that made grafting easier and more secure, helping in the aim of achieving the best fixation of the two ends to be tension free [8]. Of course, surgical technique and the experience of the surgeon have a serious input in the final outcome.

\subsubsection{Neurotization}

The process of neurotization is a procedure in which undamaged motor nerved is transferred to another, injured nerve, and this undamaged nerve can come from the brachial plexus (known as intraplexus transfer), or from 
elsewhere (known as extraplexus transfer). Suturing the transferred nerve close to the motor units and not using nerve grafts are improving the final outcome $[20,21,22]$. There are some authors $[11,23]$ that have indicated the influence of the primary reconstructed brachial plexus injuries, increasing the chance for reinnervation of the antagonist group of muscles.

\subsubsection{Intraplexus transfer option}

There are a few options for intraplexus transfers to be done, described later.

Radial nerve transfer to the axillary nerve, in which branch from the radial nerve is transferred to the injured axillary nerve, posterior branch. With this procedure the clinical outcome seen in a treated patient demonstrated good results with more than 120-degree shoulder abduction. The result is boosted when this procedure is combined with neurotization of the accessory nerve with the suprascapular nerve [24, 25].

Ulnar nerve transfer to musculocutaneous nerve, firstly described in 1994 from Oberlin et al. [26] provides neurotization of the ulnar nerve to the musculocutaneous nerve, motor branch, supplying the biceps and providing excellent results $[27,28]$. The best results are seen if the injury was treated six months after the trauma, with worse result in the one treated after more than 12 months after the initial trauma [24]. M3 biceps strength or more have been observed in $94-100 \%$ of the patients, and $75-94 \%$ of the patients have M4 biceps strength. Oberlin 2 surgical procedure, is a modification, in which fascicle from the median nerve has been used for neurotization of the brachial muscle motor branch. Significant difference in the outcome was not found, comparing Oberlin to Oberlin 2 surgical procedure [29].

Medial pectoral nerve transfer to musculocutaneous nerve is a procedure where the transfer of the medial thoracic nerve is done to the musculocutaneous nerve. This technique was firstly described in 2003 by Brandt and Mackinnon [30], with good functional outcome in the flexion of the elbow. This nerve can also be used not only for neurotization musculocutaneous nerve, but also for axillary, suprascapular and accessory nerve. Using this nerve as a donor remains controversial mostly because of the inappropriate diameter match, limitation in length and loss of the internal rotation of the shoulder joint [31].

\subsubsection{Extraplexus transfer option}

Few options are also available in brachial plexus surgery using extraplexus nerve donor of the root.

Phrenic nerve transfer to musculocutaneous, described for the first time in the 1990, by $\mathrm{Gu}$ et al. [32], is not recommended for children younger than two years old, and in patients that have had pre-existing pulmonary diseases, knowing the roll of the phrenic nerve in breathing. In most of the cases of brachial plexus injury, the phrenic nerve is, in general, undamaged and knowing that $\mathrm{C} 3$ and $\mathrm{C} 4$ spinal nerve gives the biggest contribution to its existing, makes the phrenic nerve a good candidate for donor nerve. The dissection of the phrenic nerve needs to go as lower as possible, giving chance not to have need to use a nerve graft.

Phrenic nerve transfer to suprascapular nerve, is an option that needs to be considered instead of the spinal accessory nerve to suprascapular, giving in advice the short distance to the effector area and shorter period that need to be waited, for the recovery of the function, resulting with good outcomes [32]. This type of neurotization should be avoided if simultaneously nerve transfer from the intercostal nerve has been considered.

Accessory nerve transfer to suprascapular nerve, it is likely the most often used type of nerve transfer, for the reason of the frequency of the suprascapular nerve injuries and the easiness in performing the procedure. Due to the close relation of these two nerves it allows using the same route for exploration of the injuries of the brachial plexus. Shoulder stability achieved with this procedure boost elbow flexion, but provide unsatisfactory external rotation of the shoulder and abduction of 66 degrees in $60 \%$ of the patients [22].

Contralateral $\mathrm{C} 7$ to the median nerve was described in 1992, by Gu et al. [33], introducing the $\mathrm{C} 7$ root from the contralateral side to be harvested and using nerve graft, usually ulnar nerve from the injured side, connected to the median nerve. Numbness of the fingers (thumb, index, and long finger) are usually found on the donor side in the first 3 months from the operation, decreased grip strength but not affecting the pinch strength [34]. Because of the distance between the contralateral $\mathrm{C} 7$ root and the recipient nerve, which is about $30 \mathrm{~cm}$, the used nerve graft needs to be vascularised or this procedure to be done in two stages, maintaining the regenerative potential of C7 [35]. 
Intercostal nerve transfer to musculocutaneous nerve, is a procedure where the intercostal nerve, its motor branch, is transferred to the musculocutaneous nerve. The dissection of the intercostal nerve is as close to the sternal region [36], to provide acceptable length by avoiding using the nerve grafts. The repair of the elbow flexion with this technique provides good results, which can be worsen by these factors: surgical treatment five months after trauma, bad adaptation of the ends, use less than three intercostal nerves, using of the grafts or tension at the suture line and shoulder instability [37].

\subsubsection{Arthrodesis}

As a procedure, arthrodesis means surgical immobilization of the joints, by fusion of the bones, and these type of surgery was used in the patient with brachial plexus injuries until the 1960s, among other procedures, as external derotation osteotomy, wrist arthrodesis and limb amputations [38]. Intact acromioclavicular, sternoclavicular and scapulothoracic joint need to be present, otherwise it may affect the success of the arthrodesis of the shoulder. Shoulder joint should be fussed in 20 degrees abduction, 30 degrees of internal rotation and flexion, providing independent daily activities of the patient if the motion mobility of the hand is preserved or repaired with nerve transfer or nerve grafts. Wrist arthrodesis, as a complementary procedure, releases the patient from the wrist pain and also gives stability to the hand, helping and improving the performance of the patient daily activities, more superior if double free muscle transfer for hand function was performed $[39,40]$. Improvements that have been done in the field of nerve transfers and free muscle transfers have significantly changed the way of the brachial plexus injuries treatment and has made arthrodesis exceptional approach.

\subsubsection{Tendon transfer}

There are more options for tendon transfers in the surgical treatment of the brachial plexus injuries. A transfer to be successful needs to be done by following the basic principles, but the muscle strength is almost always, at least, one grade lower on the measurement scale.

For maintaining the shoulder stability, plenty of tendon transfer techniques exist [41], but the most used ones are:
The transfer of the trapezium muscle, acromial insertion, to the upper part of the humerus (together with a segment of the acromion) maintaining shoulder abduction, or transfer of the lower parts of the trapezium muscle to the intertuberous sulcus, using graft from fascia lata or maximal dissection and using aponeurotic tissue, gaining external rotation [42, 43].

The transfer of the latissimus muscle, as another surgical procedure that provides external rotation, was described by L' Episcopo firstly, with modification of this technique later. The surgical procedure consists of transferring the latissimus dorsi tendon insertion from its normal anatomical position, on the front medial side of the humerus to the new position on the lateral and back side, helping the external rotation.

Transfer of the posterior part of the deltoid muscle restoring anterior segment deficit.

Elbow flexion restoration influences, at most, the final functional and clinical result after treatment of the brachial plexus injuries. Stable and mobile elbow, with sufficient flexion strength is crucial for acceptable upper limb function [44]. Restoring good muscle strength and providing a sufficient range of elbow motion is a goal that needs to be achieved with one of the following surgical procedures:

Flexor-pronator muscle transfer for the humerus [45], illustrated for the first time in 1918, by Steindler, consists of transfer of the flexor forearm muscle to a proximal section, metaphyseal region of the humeral bone. The results are better if the bone is fixed closer than $5 \mathrm{~cm}$ to the medial epicondyle and the existing elbow flexor musculature has the grade 2, at least, with bad outcome in the total elbow paralysis. C8 and T1 nerve roots need to be undamaged for this technique to achieve success in treating patient.

Greater pectoral muscle transfer to biceps muscle, also known as Clark technique [46], can be used when pectoral muscle innervation is intact, that is unusual knowing the innervation of the pectoral muscle. Shoulder arthrodesis is mandatory, because distal suture of the pectoral muscle to the biceps muscle is not tension free, muscle to muscle suture type.

Latissimus dorsi muscle transfer to the biceps muscle, is another type of surgical technique providing elbow flexion, with great strength, but very often this muscle innervation (thoracodorsal nerve) is damaged in the brachial plexus injuries 
[47]. Preoperative strong latissimus muscle and well passive extension of the elbow are needed for successful unipolar transfer of the latissimus muscle to have good outcome, functional, but also providing good aesthetic outcome [48].

Triceps muscle transfer to biceps muscle is a technique in which the distal part of the triceps tendon is detached, and, then, transferred to the tendon of the biceps. With this transfer, good elbow flexion can be achieved after the process of rehabilitation, where the triceps muscle will learn its new function, but the active extension of the elbow will be lost, making this procedure unwanted for patients who depend on using wheelchair or crutches. Good functional result and solid evaluation from the patients are found in most of the cases, except in cases of inadequate tension at the level of the tendon suture line [49].

\subsubsection{Free muscle transfer}

Free muscle transfer as a surgical procedure for restoring the function of the upper limb is developed in the last years, together with the development of the microsurgical technique and the consecutive microneural adaptation to the recipient nerve. Tamai et al. [50] in 1970 reported on the first free muscle transfers in dogs that introduce this type of procedure as successful. Free muscle transfer procedure needs to be considered in a patient with brachial plexus injury, with or without preexisting treatment, with no clinical and functional sign of recovery after 9-12 months from the trauma [51, 52]. Accessory nerve, intercostal nerves, fascicle of ulnar nerve or sural nerve are used as a donor motor nerve, providing neurotization to the transferred free muscle in severe trauma of the brachial plexus. Vessels anastomosis and precise adaptation of the nerves are prerequisite for successful free functional muscle transfer. Rectus femoris and gracilis muscle are the ones that are used mostly as a donor muscle $[54,55]$, followed by latissimus dorsi muscle, greater thoracic and tensor iliotibial band muscle [56].

\subsubsection{Bionic reconstruction}

In the last few years, bionic reconstruction as a novel treatment approach has been described for treatment of the severe cases with BPI, where there wasn't an improvement in the hand or arm function after the primary and secondary reconstruction procedures. Free muscle or nerve trans- fer is done first to secure an electromyographic signal sites that will provide control of the bionic hand. The functionless hand is then amputated at the transradial or transhumeral level, depending on the function of the elbow, or even a glenohumeral amputation is performed. It is very important this kind of treatment to be done in carefully selected patients that understood the irreversibility of the treatment options and the need of intense process of rehabilitation and learning [57].

\section{REFERENCES}

1. Johnson EO, Vekris M, Demesticha T, Soucacos PN. Neuroanatomy of the brachial plexus: normal and variant anatomy of its formation. Surg Radiol Anat. 2010 Mar; 32(3): 291-7.

2. Catala M, Kubis N. Gross anatomy and development of the peripheral nervous system. Handb Clin Neurol. 2013; 115: 29-41.

3. Sakellariou VI, Badilas NK, Mazis GA, et al. Brachial plexus injuries in adults: evaluation and diagnostic approach.-ISRN Orthop. 2014; 2014: 726103. Published 2014 Feb 9. doi:10.1155/2014/726103.

4. Pondaag W, Malessy M, van Dijk JG, Thomeer R. Natural history of obstetric brachial plexus palsy: A systematic review. Dev Med Child Neurol. 2004; 46: 138-44.

5. Andrew T, Wallace WA. Do brachial plexus injuries occur at initial impact in motor-cyclists. $\mathrm{Br}$ Med-J.-1978; 1(6): 1668.

6. Midha R. Epidemiology of brachial plexus injuries in a multitrauma population. Neurosurgery. 1997; 40(6): 1182-8.

7. Rorabeck $\mathrm{CH}$, Harris WR. Factors affecting the prognosis of brachial plexus injuries. J Bone Joint Surg Br. 1981; 63-B(3): 404-7.

8. Seddon HJ. A Classification of Nerve Injuries. $\mathrm{Br}$ Med J. 1942; 2(4260): 237-9.

9. Bateman JE. An operative approach to supraclavicular plexus injuries. J Bone Joint Surg Br. 1949; 31B(1): 34-6.

10. Seddon HJ. Nerve Grafting. J Bone Joint Surg Br. 1963; 45: 447-61.

11. Bertelli JA, Ghizoni MF. Results and current approach for Brachial Plexus reconstruction. J Brachial Plex Peripher Nerve Inj. 2011; 6(1): 2.

12. Snell RS. Clinical Anatomy. 8th edition. Lippincott Williams \& Wilkins; 2007.

13. Senecail B. Le plexus brachial de l'Homme [Ph.D. thesis] 1975.

14. Kerr A. Brachial plexus of nerves in man. The variations in its formation and branches. American Journal of Anatomy. 1918; 23. 
15. de Sèze MP, Rezzouk J, de Sèze M, Uzel M, Lavignolle B, Midy D, Durandeau A (2004). "Does the motor branch of the long head of the triceps brachii arise from the radial nerve?". Surg Radiol Anat. 26 (6): 459-461. doi: 10.1007/ s00276-004-0253-z. PMID 15365769.

16. Swanson AN, Wolfe SW, Khazzam M, Feinberg J, Ehteshami J, Doty S. Comparison of neurotization versus nerve repair in an animal model of chronically denervated muscle. J Hand Surg Am. 2008; 33(7): 1093-9.

17. Songcharoen P, Wongtrakul S, Spinner RJ. Brachial plexus injuries in the adult. nerve transfers: the Siriraj Hospital experience. Hand Clin. 2005; 21(1): 83-9.

18. Millesi H. Brachial plexus injuries. Management and results. Clin Plast Surg. 1984; 11(1): 115-20.

19. Millesi H. Brachial plexus injuries. Nerve grafting. Clin Orthop Relat Res. 1988: 36-42.

20. El-Gammal TA, Fathi NA. Outcomes of surgical treatment of brachial plexus injuries using nerve grafting and nerve transfers. J Reconstr Microsurg. 2002; 18(1): 7-15.

21. Rohde RS, Wolfe SW. Nerve transfers for adult traumatic brachial plexus palsy (brachial plexus nerve transfer) HSS J. 2006; 3(1): 77-82.

22. Venkatramani H, Bhardwaj P, Faruquee SR, Sabapathy SR. Functional outcome of nerve transfer for restoration of shoulder and elbow function in upper brachial plexus injury. J Brachial Plex Peripher Nerve Inj. 2008; 3: 15.

23. Flores LP. Brachial plexus surgery: the role of the surgical technique for improvement of the functional outcome. Arq Neuropsiquiatr. 2011; 69(4): $660-5$.

24. Merrell GA, Barrie KA, Katz DL, Wolfe SW. Results of nerve transfer techniques for restoration of shoulder and elbow function in the context of a meta-analysis of the English literature. J Hand Surg Am. 2001; 26(2): 303-14.

25. Terzis JK, Kostas I. Suprascapular nerve reconstruction in 118 cases of adult posttraumatic brachial plexus. Plast Reconstr Surg. 2006; 117(2): 613-629. doi:10.1097/01. prs.0000203410.35395.fa.

26. Oberlin C, Beal D, Leechavengvongs S, Salon A, Dauge MC, Sarcy JJ. Nerve transfer to biceps muscle using a part of ulnar nerve for C5-C6 avulsion of the brachial plexus: anatomical study and report of four cases. J Hand Surg Am. 1994; 19(2): 232-7.

27. Vekris MD, Beris AE, Johnson EO, Korobilias AV, Pafilas D, Vekris AD, et al. Musculocutaneous neurotization to restore elbow flexion in brachial plexus paralysis. Microsurgery. 2006; 26(4): 325-9.

28. Teboul F, Kakkar R, Ameur N, Beaulieu JY, Oberlin C. Transfer of fascicles from the ulnar nerve to the nerve to the biceps in the treatment of upper brachial plexus palsy. J Bone Joint Surg Am. 2004; 86-A(7): 1485-90.

29. Sungpet A, Suphachatwong C, Kawinwonggowit V, Patradul A. Transfer of a single fascicle from the ulnar nerve to the biceps muscle after avulsions of upper roots of the brachial plexus. J Hand Surg Br. 2000; 25(4): 325-8.

30. Brandt KE, Mackinnon SE. A technique for maximizing biceps recovery in brachial plexus reconstruction. J Hand Surg Am. 1993;18(4):726-33.

31. Park TS. Medial pectoral nerve transfer. J Neurosurg Pediatr. 2009; 3: 345-346. doi: 10.3171/2008.12.PEDS08370.

32. Gu YD, Wu MM, Zhen YL, Zhao JA, Zhang GM, Chen DS, et al. Phrenic nerve transfer for treatment of root avulsion of the brachial plexus. Chin Med J (Engl) 1990; 103(4): 267-70.

33. Gu YD, Zhang GM, Chen DS, Yan JG, Cheng $\mathrm{XM}, \mathrm{Chen} \mathrm{L}$. Seventh cervical nerve root transfer from the contralateral healthy side for treatment of brachial plexus root avulsion. J Hand Surg Br. 1992; 17(5): 518-21.

34. Dong Z, Cheng XM, Gu YD. The regular pattern of early sensory and motor changes of the healthy hand after $\mathrm{C} 7$ transfer and its clinical significance. Chin J Hand Surg (Chin) 1997;6(1):242-4.

35. Zhang CG, Gu YD. Contralateral C7 nerve transfer - Our experiences over past 25 years. J Brachial Plex Peripher Nerve Inj. 2011; 6(1): 10. Published 2011 Nov 23. doi:10.1186/1749-72216-10.

36. Malessy, M. A., \& Thomeer, R. M. (1998). Evaluation of intercostal to musculocutaneous nerve transfer in reconstructive brachial plexus surgery, Journal of Neurosurgery, 88(2), 266-271.

37. Chuang DC, Yeh MC, Wei FC. Intercostal nerve transfer of the musculocutaneous nerve in avulsed brachial plexus injuries: evaluation of 66 patients. J Hand Surg Am. 1992; 17(5): 822-828. doi: 10.1016/0363-5023(92)90451-t.

38. Pfeil J, Martini AK. [Indications and results of shoulder arthrodesis and concomitant myoplastic interventions. Follow-up of 60 patients] Z Orthop Ihre Grenzgeb. 1985; 123(5): 872-5.

39. Terzis JK, Barmpitsioti A. Wrist fusion in posttraumatic brachial plexus palsy. Plast Reconstr Surg. 2009; 124(6): 2027-2039. doi:10.1097/ PRS.0b013e3181bcefe0.

40. Addosooki A, Doi K, Hattori Y, Wahegaonkar A. Wrist arthrodesis after double free-muscle transfer in traumatic total brachial plexus palsy. Tech Hand Up Extrem Surg. 2007; 11(1): 29-36. doi:10.1097/bth.0b013e31802e92a5.

41. Elhassan B, Bishop A, Shin A, Spinner R. Shoulder tendon transfer options for adult patients with brachial plexus injury. J Hand Surg 
Am. 2010;35(7): 1211-1219. doi:10.1016/j. jhsa.2010.05.001.

42. Monreal R, Paredes L, Diaz H, Leon P. Trapezius transfer to treat flail shoulder after brachial plexus palsy. J Brachial Plex Peripher Nerve Inj. 2007; 2: 2. Published 2007 Jan 12. doi:10.1186/17497221-2-2.

43. Saha AK. Surgery of the paralysed and flail shoulder. Acta Orthop Scand. 1967; 5-90. doi: 10.3109/ort.1967.38.suppl-97.01.

44. Morrey BF, Askew LJ, Chao EY (1981) A biomechanical study of normal functional elbow motion. J Bone Joint Surg [Am] 63: 872-877.

45. MAYER L, GREEN W. Experiences with the Steindler flexorplasty at the elbow. J Bone Joint Surg Am. 1954; 36-A(4).

46. CLARK JM. Reconstruction of biceps brachii by pectoral muscle transplantation. Br J Surg. 1946; 34(134): 180. doi:10.1002/bjs.18003413408.

47. Zancolli E, Mitre H. Latissimus dorsi transfer to restore elbow flexion. An appraisal of eight cases. J Bone Joint Surg Am. 1973; 55(6): 1265-1275.

48. Sonia Chaudhry, Sevan Hopyan, Bipolar latissimus transfer for restoration of elbow flexion, Journal of Orthopaedics, Volume 10, Issue 3, 2013, Pages 133-138, ISSN 0972-978X.

49. Souza FI, Saito M, Kimura LK, Júnior RM, Zumiotti AV. Muscle transfer from triceps to biceps in patients with chronic injury of the upper trunk of the brachial plexus. Rev Bras Ortop. 2015; 45(4): 409-412. Published 2015 Nov 17. doi: 10.1016/S2255-4971(15)30389-X.

50. Tamai S, Komatsu S, Sakamoto H, Sano S, Sasauchi N. Free muscle transplants in dogs, with microsurgical neurovascular anastomoses. Plast Reconstr Surg. 1970; 46(3): 219-225. doi: 10.1097/00006534-197009000-00002.
51. Chuang DC. Neurotization and free muscle transfer for brachial plexus avulsion injury. Hand Clin. 2007; 23(1): 91-104. doi: 10.1016/j. hcl.2007.02.001.

52. Akasaka Y, Hara T, Takahashi M. Free muscle transplantation combined with intercostal nerve crossing for reconstruction of elbow flexion and wrist extension in brachial plexus injuries. Microsurgery. 1991; 12(5): 346-351.

53. Manktelow RT, Zuker RM, McKee NH. Functioning free muscle transplantation. J Hand Surg Am. 1984;9A(1):32-9.

54. Barrie KA, Steinmann SP, Shin AY, Spinner RJ, Bishop AT. Gracilis free muscle transfer for restoration of function after complete brachial plexus avulsion. Neurosurg Focus. 2004; 16(5): E8. Published 2004 May 15. doi: 10.3171/ foc.2004.16.5.9.

55. Berger A, Flory PJ, Schaller E. Muscle transfers in brachial plexus lesions. J Reconstr Microsurg. 1990; 6(2): 113-116. doi: 10.1055/s-20071006809.

56. Favero KJ, Wood MB, Meland NB. Transfer of innervated latissimus dorsi free musculocutaneous flap for the restoration of finger flexion. J Hand Surg Am. 1993; 18(3): 535-540. doi:10.1016/0363-5023(93)90108-f.

57. Hruby LA, Pittermann A, Sturma A, Aszmann OC. The Vienna psychosocial assessment procedure for bionic reconstruction in patients with global brachial plexus injuries. PLoS One. 2018 Jan 3; 13(1): e0189592. doi: 10.1371/journal. pone.0189592. PMID: 29298304; PMCID: PMC5751989. 


\title{
Резиме
}

ПОВРЕДИ НА РАМЕНИОТ НЕРВЕН СПЛЕТ ПРЕГЛЕД НА АНАТОМИЈА И ОПЦИИ ЗА ТРЕТМАН

\author{
Софија Пејкова ${ }^{1}$, Венко Филипче ${ }^{2}$, Игор Пеев ${ }^{1}$, Бисера Николовска ${ }^{1}$, \\ Томислав Јованоски ${ }^{1}$, Гордана Георгиева ${ }^{1}$, Благоја Србов ${ }^{1}$ \\ ${ }^{1}$ ЈЗУ УК за Пластична и реконструктивна хирургија, Скопје, РС Македонија \\ ${ }^{2}$ ЈЗУ УК за неврохирургија, Скопје, РС Македонија
}

Повредите на рамениот нервен сплет сѐ уште се хируршки предизвик за секој хирург што третира пациенти со повреди на БП. Повредите на брахијалниот плексус можат да се поделат на повреди на горното стебло, проширен тип на повреда, повреди на долното стебло и комплетна лезија на сите корени со висечка рака. Разликуваме пет анатомски делови на брахијалниот плексус: корени, стебла, дивизии, снопови и завршни гранки. Завршува со пет терминални гранки одговорни за инервација на горниот екстремитет, мускуло-кожниот нерв, средиштен нерв, пазувен нерв, радијалниот нерв и улнарниот нерв. Во зависност од добиените резултати од предоперативно направените иследување, во комбинација со функционалниот дефицит откриен при клиничкиот преглед, типот на повреда на БП ќе биде установена и ќе се одлучи која е соодветната хируршка процедура за третман на пациентот од повеќето можни процедури (невролиза, нервен трансплантат, невротизација, артродеза, трансфер на тетиви, слободен мускулен трансфер, бионичка реконструкција), кои се употребуваат при третман на повреди на брахијалниот плексус.

Клучни зборови: ПБП, повреди на брахијален плексус, опции за третман за повреди на брахијалниот плексус, бионичка реконструкција 